\title{
The Basic of Deposit Money Compensation in the Land Acquisition For Public Interest
}

\author{
Suyanto $^{1,2^{*}}$, Made Warka ${ }^{3}$, Slamet Suhartono ${ }^{4}$, Sri Setyadji ${ }^{4}$ \\ 1. Doctoral Candidate of the Faculty of Law Universitas 17 Agustus 1945 Surabaya, Indonesia \\ 2. Dean and Lecturer Faculty of Law Universitas Gresik, Gresik, Indonesia, PO box 6111 \\ 3. Professor in Law, Faculty of Law Universitas 17 Agustus 1945 Surabaya, Indonesia \\ 4. Associate Professor in Law, Faculty of Law Universitas 17 Agustus 1945 Surabaya, Indonesia
}

\begin{abstract}
Land procurement for the public interest is pursued through land acquisition. Land acquisition for public interest is regulated in Law No. 2 of 2012 and the implementing regulations. The part that needs land is an agency. Land procurement is taken through the release of rights by the rightful part with proper and fair compensation. Determination of the form and/ or amount of compensation for the object of land acquisition is preceded by deliberation between the Land Procurement Executor and the rightful part. If the deliberation reaches an agreement, an official report is made between the Land Procurement Executor and the rightful part. If the deliberation doesn't reach an agreement, then the compensation is deposited by the agency that needs land in the local District Court. The basic of the implementation deposit of compensation in the District Court in the land acquisition for public interest is not based on an agreement in the deliberation which is denied by the rightful part, but it's based on the determination of compensation that is issued by the Chief of Land Procurement Executor. In contrast to the basic of the provision of deposit (consignment) in Article 1404 (Burgerlijk Wetboek) which requires deposit, there must be a legal relationship first.
\end{abstract}

Keywords: Land acquisition, deposit, compensation, consignment.

DOI: $10.7176 / \mathrm{JLPG} / 83-16$

Publication date: March $31^{\text {st }} 2019$

\section{Introduction}

National development is carried out by the Government, Provincial Governments, Regency / City Governments, Authority Foundation, State-Owned Enterprises, Regionally-Owned Enterprises, private companies, and the general public. The implementation of national development requires land as a place of activity because basically national development is carried out on land. Land needed to carry out national development can be used for building purposes, or cultivated for agricultural, fishery, livestock and plantation purposes.

Land does not only have an important role in national development. Land also has important meaning in human life because it has a dual function, namely social assets and capital assets. As a social asset, land is a means of binding social unity among Indonesian people for life and life, whereas as a capital asset, land is a capital factor in development (Yulis, 2000). Increased development activities can bring consequences that the land no longer has social value, but has become an economic value, meaning that people own or control land not just for shelter or occupancy, but have been oriented to gain profit (Santoso, 2012). The rapid development carried out by the Government, Regional Governments, and private companies that need land rights can result in soaring land prices so that land can become an economic commodity, namely people owning or controlling land rights aiming for profit or land for investment (Suyanto \& Arif, 2017).

The status of land needed by the Government, Regional Government, State-Owned Enterprises, RegionallyOwned Enterprises, and private companies can be in the form of state land, communal land, or land rights. The status of the part wishing to control land rights can be in the form of a public legal entity or private legal entity. The desire of holders of land rights is needed to release their land through the transfer of land rights or the release of land rights by providing proper and fair compensation.

At present, land acquisition for public interest is regulated in Law No. 2 of 2012 concerning Land Procurement for Development in the Public Interest. Law No. 2 of 2012 implemented by Republic of Indonesia's Presidential Regulation No. 71 of 2012 concerning the Implementation of Land Procurement for Development in the Public Interest, as amended by the fourth by Republic of Indonesia Regulation No. 148 of 2015 concerning the Fourth Amendment to RI President Regulation No. 71 of 2012 concerning the Implementation of Land Acquisition for 
Development in the Public Interest, and Regulation of the Head of the Indonesian National Land Agency No. 5 of 2012 concerning Technical Guidelines for the Implementation of Land Acquisition.

In the procurement of land for the public interest there is a discussion between the parties who are entitled to compensation and the Land Procurement Executor (LPE), by involving agencies that need land. The purpose of the deliberation is to agree on the form and / or amount of compensation. One of the problems in the procurement of land for urgent public interest is not yet reached an agreement regarding the form and / or the amount of compensation between the entitled parties and agencies that need land. To resolve compensation issues, the rule of law concerning compensation is determined. Article 42 of Law No. 2 of 2012 stipulates the reason for compensation payments in the form of money in the District Court.

The term consignment in line of the term deposit for compensation of money in the acquisition of land for public interest is deposited in the District Court (Tehupeiory, 2017). Several development projects in the procurement of land for the public interest for toll roads in the form of money were deposited in the District Court. The toll road construction from Bunder Gresik to Krian Sidoarjo was deposited to the Gresik District Court to the Surabaya District Court, the construction of the toll road from Jombang to Kertosono was compensated to the Jombang District Court.

This study aims to find the basic occurrence of consignment in the perspective of Civil Law and find the basic occurrence of deposit in money compensation in the District Court in the procurement of land for the public interest.

\section{Research Design}

The design of this study uses normative legal research, which is research that puts law as a system of norms, namely regarding principles, norms, legislation, court decisions, agreements and doctrines (teachings) (Achmad and Yulianto, 2010). More specifically, legal research is a process to find legal rules and legal doctrines in order to answer legal issues faced (Marzuki, 2009). The legal issues raised in this study need legal research, namely a process to find legal rules, legal principles, and legal doctrines in order to answer the legal issues faced (Hernoko, 2011).

The legal material collection technique in this study begins with a literature study, namely an inventory of all legal materials related to the subject matter, both primary legal material, and secondary legal material. Primary legal materials include: 1945 Constitution of the Republic of Indonesia; Law Number 5 of 1960 concerning Basic Agrarian Principles; Law Number 20 of 1961 concerning Revocation of Land Rights and Objects Above it; Law Number 2 of 2012 concerning Land Procurement for Development in the Public Interest; Presidential Regulation No. 36 of 2005 concerning Land Procurement for the Implementation of Development in the Public Interest; Presidential Regulation Number 65 of 2006 concerning Amendments to Perpres Number 36 Year 2005 concerning Land Procurement for the Implementation of Development for Public Interest; Presidential Regulation Number 71 of 2012 concerning Implementation of Land Procurement for Development in the Public Interest; Presidential Regulation No. 148 of 2015 concerning the Fourth Amendment to Presidential Regulation Number 71 of 2012 concerning the Implementation of Land Procurement for Development in the Public Interest; Head Regulation of the National Land Agency Number 5 of 2012 concerning Technical Guidelines for the Implementation of Land Acquisition; Minister of Agrarian and Spatial Planning / Head of the National Land Agency Number 6 of 2015 concerning Amendments to the Regulation of the Head of the National Land Agency Number 5 of 2012 concerning Technical Guidelines for the Implementation of Land Acquisition.

Secondary legal material, namely legal material that provides an explanation of primary legal materials, such as literature studies and study of documentation, archives, official government data, legal books, legal papers, legal journals, legal magazines, and the results of previous research related to this research.

The next stage of research is the classification of related legal materials, namely legal materials are arranged systematically to more easily read and study them. Legal materials obtained from library studies, then collected and grouped, to be selected and sorted according to the character of the legal material needed; especially those that have relevance to the issues discussed. For legal material that is less relevant, it is temporarily set aside, and will be used if the legal material is needed.

Analysis of legal material is carried out by first identifying the legal material collected, then described, systematized by basicly it on the scientific theory of law and concepts of legal science, principles or legal principles. Furthermore, the analysis of legal material used in this study is qualitative juridical analysis, namely analysis that basic on legal reasoning, legal interpretation, and coherent legal argumentation. The use of such 
legal material analysis is expected to explain the problems formulated in this study satisfactorily.

\section{Result and Discussion}

\subsection{Deposit of Money (Consignment) in Courts on the Perspective of Civil Law}

Etymologically, the consignment term in English comes from consign, consigmen means to give, send, submit as safekeeping (Echol \& Shadily, 2006). In Dutch, consignment comes from the word consignatie, meaning the deposit of money or goods in the court for payment of debt or referring to the stage of storage (Hamzah, 1986).

Provisions regarding consignment in the perspective of the Civil Code (Burgerlijk Wetboek) are regulated in Article 1404, namely: "If the debtor refuses payment, the debtor can offer cash payments what is owed, and the debtor refuses, leaves the money or goods to the court. Such an offer, followed by safekeeping, freeing the debtor, and applying to him as payment, provided that the offer has been carried out according to the Act, while what is entrusted with it remains at the expense of the debtor "(Subekti \& Tjitrosudibio, 1985).

Engagement made by parties can be deleted. The removal of the agreement is stipulated in Article 1381 of the Civil Code (Burgerlijk Wetboek), namely: due to payment; because of the offer of cash payments, followed by deposit or deposit; because of debt renewal; because of a debt or compensation meeting; because of debt mixing; because of debt relief; because of the loss of goods owed; due to cancellation or cancellation; because the entry into force of a condition is canceled; because of the passage of time.

The law makes it possible for debtors to repay debts by offering cash payments followed by depositing money in the District Court. With the action of offering cash payments followed by consignment, the debtor has been released from payment resulting in the removal of the agreement. This is in accordance with the provisions of Article 1381 of the Civil Code (Burgerlijk Wetboek) which determines that one way to abolish the agreement is by offering cash payments followed by consignment (Harahap, 1986).

The offer of cash payments followed by safekeeping is only possible in an agreement in the form of a payment of money or an agreement to give up a moving object so that the object of achievement of doing or not doing something or leveraging immovable objects is not possible. (Muwahid, 1986).

One of the deletions of the engagement is because of the offer of cash payments, followed by deposit or safekeeping, as stipulated in Article 1381 letter b of the Civil Code (Burgerlijk Wetboek). The cancellation of the engagement is due to the offer of cash payments, followed by deposit or safekeeping stipulated in Articles 1404 to Article 1412 of the Civil Code (Burgerlijk Wetboek).

Provisions regarding the offer of cash payments, followed by storage or safekeeping (consignment) are stipulated in Article 1404 of the Civil Code (Burgerlijk Wetboek), namely: "If the debtor refuses payment, then the debtor can offer cash payments what is owed, and the debtor rejects it, entrusts money or goods to the court. Such an offer, followed by safekeeping, freeing the debtor, and applying to him as payment, provided that the offer has been carried out according to the Act, while what is entrusted with it remains at the expense of the debtor "(Subekti \& Tjitrosudibio, 1985).

Aartje Tehupeiory (2017) gives meaning from the provisions of Article 1404 of the Civil Code (Burgerlijk Wetboek), namely: "If the creditor refuses payment from the debtor, then the debtor has the right to make the cash or debt payment offer, and if the creditor rejects it, the debtor leave the payment in the District Court. The payment offer followed by deposit payment in the District Court applies as payment for the debtor and releases the debtor from the debt originating from the offer in accordance with the Law and what is deposited in the District Court as the payment is at the creditors' expense.

In connection with Article 1404 of the Civil Code (Burgerlijk Wetboek), M. Yahya Harahap (1986) states that: "The law allows debtors to settle debt agreements by offering cash payments followed by depositing money in the District Court. With the offer of cash payments followed by consignment, the debtor has been released from payment resulting in the abolition of the agreement. Fill in accordance with the provisions of Article 1381 which determines that one of the ways to abolish the agreement is by offering cash payments followed by consignment ".

Based on the provisions of Article 1404 of the Civil Code (Burgerlijk Wetboek), if the creditor refuses payment from the debtor, then the debtor has the right to offer his debt payment and if the creditor rejects it, then the debtor leaves the payment in court. The payment offer followed by deposit of payment in the court applies as a payment to the debtor and frees the debtor from the debt as long as the offer is in accordance with the Act and what is deposited in the court as the payment is borne by the creditor. 
In the event that payment can occur through consignment if the debtor has made a payment offer, then the creditor rejects the offer. For the creditor's refusal, the debtor entrusts the payment to the District Court to keep it As such, the commitments made by the parties are removed accordingly. As a result of the consignment law, the debtor has been deemed to carry out his obligations to fulfill his achievements. Article 1405 The Civil Code (Burgerlijk Wetboek) stipulates the validity of the offer, namely: "In order for such an offer to be valid, it is necessary to:

1) that it is done to someone with debt or to a person who has the power to accept it for that;

2) that it is done by a person in power to pay"

3) that he has debited all principal and interest that can be collected along with the costs that have been deposited and regarding a sum of money for costs that have not been determined without reducing the later stipulations;

4) that the provisions of time have arrived, if they are made for the benefit of the debtor;

5) that the conditions by which the debt has been made have been fulfilled;

6) that an offer is made in a place, where according to the agreement the payment must be made and if there is no special agreement regarding that, to the person with personal debt or in a real place of residence or in the place of residence he has chosen;

7) that the offer is carried out by a notary or bailiff, both accompanied by two witnesses "(Subekti \& Tjitrosudibio, 1985).

Aartje Tehupeiory (2017) states that in order to fulfill the validity of the consignment material requirements and formal conditions of consignment are needed, namely: "Material requirements are conditions regarding the subject and object in the engagement to be abolished by consignment. It can be said that consignment occurs if before it is preceded by an agreement of engagement. Formal requirements are conditions regarding the subject and object that are related to the procedure for implementing the consignment. Consignment is an event legal institution provided by the Law for debtors to carry out their obligations with the help of public officials, namely courts or notaries.

Based on the provisions of Article 1405 of the Civil Code (Burgerlijk Wetboek), the bidding procedure is regulated and carried out by a notary or bailiff accompanied by two witnesses. If the creditor rejects the offer, the debtor sues the creditor in the District Court with an application for a valid bid. Cash payment offers have not freed the debtor from the engagement. An exemption occurs when a cash payment offer is followed by a deposit of money or objects to be submitted in the District Court. Therefore, the offer followed by the deposit is strengthened as payment and elimination of the agreement. What is deposited by the debtor is borne by the creditor. For the validity of the safekeeping, it is necessary to have an acceptance from the creditor or even the decision of the judge stating that the legal and safekeeping offer is in force. If the creditor rejects the offer of payment, then the debtor consigns, so that the consignment is deemed valid, the debtor requests the judge / court so that the consignment is declared valuable (van vaarde verklaring). Thus, the judge who will determine the offer and safekeeping is valuable or not. (Muwahid, 1986).

Valuable statements of offers and safekeeping do not always have to be through the determination of judges. In certain cases the offer and consignment by itself are considered valuable without a decision from the judge, if the conditions have been fulfilled as stipulated in Article 1406 of the Civil Code (Burgerlijk Wetboek), which states that the power of attorney is not required and considered already sufficient:

a. if the consignment is preceded by a notification submitted officially by the bailiff to the judge;

b. if the debtor frees himself from objects offered by surrendering objects stored in consignment cash or cash storage in the courtroom of the District Court;

c. if the bids / consignments are made for the offer and consignment, both by the notary and by the bailiff, which is attended by two witnesses;

In the consignment minutes there is a statement to reprimand the creditor for taking what is entrusted to the court, if the creditor does not appear to receive payment / submission of objects (Harahap, 1986). As for the release of the debtor in offers and safekeeping, the consequences will be as follows:

a. if the agreement is reciprocal, then the debtor can demand fulfillment of the agreement, claim compensation, demand payment of the agreement with reasons of default, and / or claim the achievement since the consignment is carried out;

b. with the consignment resulting in the debtor having to be exempted from interest payments from the date of the consignment day;

c. since the existence of a debtor consignment is exempt from the obligation of maintenance of objects as of 
the day of safekeeping, the obligation is turned into the responsibility of the creditor (Harahap, 1986).

Depositing money in the perspective of Civil Law, namely a legal institution that regulates the rejection by creditors of debtor payments, the debtor can offer cash payments for his debts. If the creditor rejects it, the debtor can do so by depositing money or goods in the District Court. The deposit of money in the perspective of Civil Law regulates the legal institutions offering cash payments followed by safekeeping of money or goods in the District Court which is based on civil relations between the debtor and creditor which starts from the relationship of accounts payable.

Consignment occurs when in an agreement, the creditor is not willing to accept the debtor's achievements. Defaults from creditors are called "mora creditoris" (Badrulzaman, 1983). If the creditor rejects the performance of the debtor, the debtor can demand the fulfillment of the agreement. To get rid of the agreement, the debtor can make a cash payment offer that is filled with safekeeping of money or goods in the District Court (consignment).

\subsection{The Basics Occurrence of Deposit Money Compensation in the District Court on Land Acquisition for Public Interest}

The implementation of land acquisition for the public interest does not always run smoothly as expected by the agency that needs land and the Land Procurement Executor (PPT). The existence of certain parties who object to the procurement of land for the public interest can be a hindrance to the successful acquisition of land in the public interest.

Problems that are found in the implementation of land acquisition for the public interest, which can be a dispute between agencies that require land and those who are entitled, namely:

a. the determination of the procurement of land for the public interest or for the benefit of private companies taking refuge behind public interests;

b. parties who need land in the land acquisition agency or private company;

c. the implementation of deliberation in the procurement of land for the public interest does not meet the decency requirements;

d. the basis or guideline in determining the amount of compensation in the acquisition of land for the public interest, which is deemed inappropriate by the rightful party;

e. indemnification safeguards in the form of money in the District Court by agencies that require land even though no agreement has been reached in the deliberations regarding the form and / or amount of compensation.

Land acquisition for public interest can be carried out if there is a compensation for the object of land acquisition by the Chief of Land Procurement. Compensation can be determined through agreements in deliberations between parties entitled to compensation and Land Procurement Executor. If in deliberations about the form and / or amount of compensation not reaching an agreement can lead to safekeeping of compensation for money in the District Court.

In a historical perspective, safekeeping in exchange for money in the procurement of land for public purposes is regulated in:

a. Article 17 Decree of the President of the Republic of Indonesia No. 55 of 1993

(1) Compensation is given directly to:

a. holders of land rights or their legal heirs;

b. nadzir for waqof land.

(2) In land, buildings, plants, or objects related to land owned together with several people, while one or several of them cannot be found, then compensation that is the right of people who cannot be found is consigned (print thick writers) in the local District Court by Government agencies that need land.

b. Article 10 of Republic of Indonesia's Presidential Regulation No. 36 of 2005

(1) In the case of development activities for the public interest which cannot be transferred or transferred, technically, the spatial layout is to another place or location, then the deliberation is conducted within a maximum period of 90 calendar days from the date of the first invitation.

(2) If after the deliberation as referred to in paragraph (1) there is no agreement, the land acquisition committee determines the form and amount of compensation as referred to in Article 13 and entrusts (bold author) compensation to the District Court whose jurisdiction covers the location the land in 
question.

(3) In the event of a ownership dispute after the stipulation of compensation as referred to in paragraph (2), the committee entrusts (the author's bold print) compensation money to the District Court whose jurisdiction covers the location of the land concerned.

c. Article 10 of Republic of Indonesia's Presidential Regulation No. 65 of 2006

(1) In the case of development activities for the public interest which cannot be transferred or transferred, technically, the spatial layout is to another place or location, then the deliberation shall be carried out within a maximum period of 120 (one hundred twenty days) from the date of the first invitation.

(2) If after the deliberation as referred to in paragraph (1) an agreement is not reached, the land acquisition committee determines the amount of compensation as referred to in Article 13 and entrusts (bold author) compensation to the District Court whose jurisdiction covers the location of the land concerned.

(3) In the event of a ownership dispute after the stipulation of compensation as referred to in paragraph (2), the committee entrusts (the author's bold print) compensation money to the District Court whose jurisdiction covers the location of the land concerned.

d. Article 48 Regulation of the Head of the National Land Agency No. 3 of 2007

(1) The Regency / City Land Procurement Committee instructs Government agencies that need land to deposit (bold writers) compensation for money to the District Courts whose jurisdiction covers the location of land for the implementation of development in terms of:

a. those who are entitled to compensation as referred to in Article 43 paragraph (1) whereabouts are unknown;

b. land, buildings, plants, and / or other objects related to land are being objects of court cases and have not obtained court decisions that have permanent legal force;

c. the ownership is still disputed and there has been no settlement agreement from the parties;

d. land, buildings, plants, and / or other objects related to the land are being seized by the court.

(2) To be able to entrust compensation as referred to in paragraph (1) and Article 37 paragraph (4), Government agencies requiring land submit a determination application to the Chair of the District Court whose jurisdiction covers the location of land for the implementation of development.

(3) Application for stipulation of safekeeping as referred to in paragraph (2) by enclosing:

a. name of the person entitled to compensation whose compensation is entrusted;

b. invitation to receive compensation payments as referred to in Article 44 paragraph (2); and

c. letters:

1) minutes of submission of compensation as referred to in Article 37 paragraph (2) and paragraph (3);

2) minutes of the results of the implementation of the construction site discussion for the public interest and determination of the form and / or amount of compensation as referred to in Article 38 ;

3) decision of the Regent / Mayor or Gubermur or Minister of Home Affairs as referred to in Article 41 paragraph (2) and paragraph (3), paragraph (4), and paragraph (7);

4) other letters in connection with safekeeping of compensation.

e. Article 42 of Law No. 2 of 2012

(1) In the event that the party has the right to reject the form and / or the amount of compensation based on the results of the deliberation or the decision of the District Court / Supreme Court, compensation shall be deposited in the local District Court.

(2) Deposit of compensation is also carried out on:

a. The party entitled to receive compensation is unknown;

b. The object of land acquisition that will be given compensation: being the object of the case in court; the ownership is still disputed; placed seized by the authorized official; or become a guarantee at the bank. 
f. Article 43 of Law No. 2 of 2012

At the time of the awarding of compensation and waiver as referred to in Article 41 paragraph (2) letter a has been implemented or compensation has been deposited in the District Court as referred to in Article 41 paragraph (1), ownership or rights to land of the rightful party to be erased and the proof of their rights is declared invalid and the land becomes land directly controlled by the state.

g. Article 86 of the Republic of Indonesia's Regulation No. 71 of 2012

(1) In the event that there is a compensation deposit, the agency requiring the land submits a request for safekeeping of compensation to the Chairperson of the District Court in the area of the construction site for the public interest.

(2) The deposit of compensation shall be submitted to the District Court in the area of the construction site in the public interest.

(3) Deposit of compensation as referred to in paragraph (2) shall be carried out in:

a. The party entitled to reject the form and / or amount of compensation is based on the results of the deliberation and does not file an objection to the court;

b. the party who has the right to reject the form and / or amount of compensation based on the decision of the District Court / Supreme Court that has obtained permanent legal force;

c. the rightful party is unknown; or

d. object of land acquisition that will be compensated: being the object of the case in court; the ownership is still disputed; placed seized by the authorized official; or become a guarantee at the bank.

(4) Forms of compensation deposited in the District Court as referred to in paragraph (1) in the form of money in rupiah currency;

(5) The implementation of the indemnity safeguards as referred to in paragraph (2) shall be made in the official report on compensation.

From the laws and regulations mentioned above, namely Article 10 of Republic of Indonesia's Presidential Regulation No. 36 of 2005, Article 10 of Republic of Indonesia's Presidential Regulation No. 65 of 2006, Article 48 of the Regulation of the Head of the National Land Agency No. 3 of 2007, Article 42 and Article 43 of Law No. 2 of 2012, and Article 86 of Republic of Indonesia's Presidential Regulation No. 71 of 2012 uses the term "safekeeping", except Article 17 of the Decree of the President of the Republic of Indonesia No. 55 of 1993 uses the term "consignment".

Article 42 of Law No. 2 of 2012 stipulates the safeguarding factors for compensation for money in the District Court, namely:

a. the party that has the right to reject the form and / or amount of compensation based on the results of the deliberation or the decision of the District Court / Supreme Court;

b. The party entitled to receive compensation is unknown;

c. The object of land acquisition that will be given compensation is being the object of the case in court;

d. The object of land acquisition that will be given compensation is still ownership disputes;

e. The object of land acquisition that will be given compensation is confiscated by the authorized official; or

$\mathrm{f}$. The object of land acquisition that will be given compensation is a guarantee at the bank.

Article 86 of the Republic of Indonesia's Regulation No. 71 of 2012 stipulates the safeguarding factors for compensation for money in the District Court, namely:

a. The party entitled to reject the form and / or amount of compensation is based on the results of the deliberation and does not file an objection to the court;

b. who has the right to reject the form and / or amount of compensation based on the decision of the District Court / Supreme Court that has obtained permanent legal force;

c. The party entitled to receive compensation is unknown;

$\mathrm{d}$. The object of land acquisition that will be given compensation is being the object of the case in court; 
e. The object of land acquisition that will be given compensation is still ownership disputes;

f. The object of land acquisition that will be given compensation is confiscated by the authorized official;or

g. The object of land acquisition that will be given compensation is a guarantee at the bank.

Deposit of compensation for money is submitted by the agency that requires land to the Chairperson of the District Court in the area of the construction site in the public interest. Indemnity deposits are submitted by agencies requiring land to the Chair of the District Court in the area of construction for public interest.

Deposit of compensation for money in the District Court in the procurement of land for public interest as stipulated in Article 42 and Article 43 of Law No. 2 of 2012 juncto Article 86 of Republic of Indonesia's Presidential Regulation No. 71 of 2012 contradicts the principle of agreement as stipulated in Article 2 letter f of Law No. 2 of 2012. Explanation of Article 2 letter $\mathrm{f}$ of Law No. 2 of 2012 provides an explanation of the principle of agreement, namely the process of land acquisition carried out by deliberations of the parties without the element of coercion to obtain a collective agreement.

The principle of agreement in the implementation of land acquisition for the public interest as stipulated in Article 2 letter f of Law No. 2 of 2012 carried out at the stage of preparation for land acquisition as stipulated in Article 19 of Law No. 2 of 2012, namely:

(1) Public consultation of the development plan as referred to in Article 18 paragraph (3) shall be carried out to obtain an agreement on the location of the development plan from the rightful party.

(2) Development Public Consultation as referred to in paragraph (1) shall be carried out by involving the rightful parties and affected communities and carried out in the place of planned development of public interest or at the agreed place.

(3) The involvement of the entitled party as referred to in paragraph (2) can be done through a representative with a power of attorney from and by the party entitled to the location of the development plan.

(4) The agreement as referred to in paragraph (1) shall be stated in the minutes of the agreement.

(5) Based on the agreement as referred to in paragraph (4), the agency requiring the land submits a request for a location determination to the governor.

(6) The Governor shall determine the location as referred to in paragraph (5) within a maximum period of 14 (fourteen) working days as of the receipt of the application for the determination by the agency requiring the land.

The principle of agreement in the implementation of land acquisition for the public interest as stipulated in Article 2 letter f of Law No. 2 of 2012 carried out at the stage of implementation of land acquisition as stipulated in Article 37 of Law No. 2 of 2012, namely:

(1) The Land Agency conducts deliberations with the entitled parties within a maximum of 30 (thirty) working days after the results of the appraisal from Panilai are submitted to the Land Agency to determine the form and / or amount of compensation based on the results of compensation assessment as referred to in Article 34.

(2) The results of the agreement in the deliberation as referred to in paragraph (1) shall become the basis for granting compensation to the rightful parties contained in the minutes of the agreement.

Article 37 of Law No. 2 of 2012 implemented by Article 72 of Republic of Indonesia's Presidential Regulation No. 71 of 2012, namely:

(1) The results of the agreement in the deliberations are the basis for granting compensation to the entitled parties as outlined in the minutes of the agreement.

(2) Minutes of agreement as referred to in paragraph (1), contain: a. The entitled party is present or the proxy agrees along with the agreed forms of compensation; b. The entitled party is present or the proxy does not agree; and c. The entitled party is absent and does not give power.

(3) The official report as referred to in paragraph (1) shall be signed by the Land Procurement Executor and the entitled party present or his proxy.

The word agreement is mentioned in Article 19 and Article 37 of Law No. 2 of 2012, and Article 72 of Republic of Indonesia's Presidential Regulation No. 71 of 2012, but in Law No. 2 of 2012 and Article 72 of Republic of Indonesia's Presidential Regulation No. 71 of 2012 as amended by the fourth by RI President Regulation No. 148 In 2015 there was no description of the meaning of the agreement. 
From the perspective of Civil Law, agreement is one of the requirements for the validity of the agreement $\mathrm{R}$. Subekti and R. Tjitrosudibio state that the legal requirements of the agreement are based on Article 1320 of the Civil Code (Burgerlijk Wetboek), namely: agreed that those who bind themselves; ability to make an engagement; certain things; a reason that is lawful or permissible.

Irawan Soerodjo (2016) states that in essence the legal requirements of the agreement in Article 1320 of the Civil Code include 4 (four) elements, namely: the existence of an agreement (consensus) from the parties; the ability to make agreements; something is agreed upon; and the existence of a reason that is lawful. An agreement is valid if an agreement has been reached on the main matters and no formality is needed. What is meant by agreement is the agreement of the parties that bind themselves. Both parties in an agreement must have the free will to bind themselves and that will must be stated both expressly and quietly.

Irawan Soerodjo stated that the agreement as one of the elements of the legal terms of the agreement has two elements, namely offer and acceptance. When meeting the offer and acceptance, that can be said as the moment of an agreement between the parties that gave birth to an agreement.

R. Subekti states that consensualism comes from the word "consensus" which means agreement. With the agreement meant that among the parties concerned is reached a conformity of will, meaning that what is desired by one is also desired by the other. Both will meet in "agreement" (Subekti, 1995).

Based on the principle of agreement as stipulated in Article 2 letter f of Law No. 2 of 2012, the implementation of land acquisition for the public interest is based on an agreement in the deliberation on the form and / or amount of compensation between the parties entitled to compensation and agencies that require land. The agreement was born from deliberation on the form and / or amount of compensation between the parties entitled to compensation and the agency that needed the land.

Law No. 2 of 2012 and the implementing regulations do not provide an understanding of deliberation. Conceptually, the meaning of deliberation in relation to land acquisition for public interest is stated in Article 1 number 10 of the Republic of Indonesia Presidential Regulation No. 36 of 2005, namely activities that contain the process of mutual listening, mutual giving and mutual acceptance of opinions, and the desire to reach agreement on the form and / or magnitude of compensation and other problems relating to land acquisition activities on the basis of voluntary and equality between parties who have land, buildings, plants, and other objects related to land with those who need land.

The definition of deliberation is an act of someone with other people to form a unified shared opinion on a problem faced by the community. As a musyawarah teaching affirms that in living in a society, all issues concerning the necessity of life and shared prosperity must be solved together by its members on the basis of their unanimous will Together (Koesnoe, 1974).

In the implementation of the deliberation, there must be no coercion by one party to the other party, the position of the parties who deliberate is equal or equal so that no party has a higher position than the other party. In the implementation of the deliberations there are activities to listen to each other with an attitude of mutual acceptance of opinions and desires based on volunteerism between those who are entitled to compensation and agencies that need land.

The agreement in the contract law (contract) is based on the principle of freedom of contract, while the agreement in the procurement of land for the public interest is based on the principle of deliberation (Gozali, 2018).

The results of other studies link deliberation in the procurement of land for this public interest by agreement as one of the legal requirements of the agreement as referred to in Article 1320 of the Civil Code (Burgerlijk Wetboek) (Limbong, 2011). The same opinion is expressed by State Use, namely deliberation does not change the agreement in the business contract agreement, namely at least two parties or more agree, one party offers and the other party accepts (Negara, 2016).

Opinions from Bernard Limbong and State Use state that agreements in deliberation in the procurement of land for public interests such as agreements as one of the legal requirements of the agreement as referred to in Article 1320 of the Civil Code (Burgerlijk Wetboek) and is based on deliberation due to determining the form and / or amount of compensation in land acquisition for public interest preceded by deliberations between parties entitled to compensation and agencies requiring land led by the Chief of Land Procurement.

The deposit of money (consignment) according to Article 1404 of the Civil Code (Burgerlijk Wetboek) can only be applied if previously there is a legal relationship between the debtor and creditor, and if the creditor rejects the agreed payment from the debtor, then the debtor will deposit money (consignment) to the local District Court. 
With the deposit of money (consignment), the debtor has carried out its obligations (Santoso, 2012).

If the creditor rejects the offer of payment, then the debtor consigns, so that the consignment is deemed valid, the debtor requests the judge / court so that the consignment is declared valuable (van vaarde verklaring). Thus, the judge who will determine the offer and safekeeping is valuable or not (Muwahid, 1986).

Deposit of compensation for money in the District Court in the procurement of land for public interest is not born from legal relations between parties entitled to compensation and agencies that need land, but are born from stipulations in the form of decisions issued by the Chief of Land Procurement caused by:

a. The party entitled to reject the form and / or amount of compensation is based on the results of the deliberation and does not file an objection to the court;

b. The party entitled to reject the form and / or amount of compensation based on the decision of the District Court / Supreme Court that has obtained permanent legal force;

c. The party entitled to receive compensation is unknown;

d. The object of land acquisition that will be given compensation is being the object of the case in court;

e. The object of land acquisition that will be given compensation is still ownership disputes;

f. The object of land acquisition that will be given compensation is confiscated by the authorized official;or

g. The object of land acquisition that will be given compensation is a guarantee at the bank.

As long as there is no agreement in the deliberation on the form and / or the amount of compensation in the procurement of land for the public interest, then there is no legal relationship between the parties entitled to compensation and agencies that need land. As long as there is no legal relationship between the party entitled to compensation and the agency that needs the land, it cannot be justified. The Chief of the Land Procurement Executor issues a decision on the amount of compensation in the acquisition of land for the public interest. With the issuance of a decision on the amount of compensation by the Chief of Land Procurement Executor entrusted to the District Court by agencies that require land, there is no other choice for those who are entitled to compensation, except taking compensation in the District Court. If the party entitled to compensation does not take compensation in the District Court, the party entitled to compensation will lose its land rights and not receive compensation.

Deposit of compensation for money in land acquisition for public purposes by agencies requiring land, which is based on the decision of the Chief of the Land Procurement Executor, is a Government policy implemented by the Chief of Land Procurement containing provisions on:

a. Acceleration of land acquisition in land acquisition for public purposes;

b. Accelerating the implementation of development projects in the public interest;

c. The development project is not neglected; and

d. The development project budget for the public interest is not forfeited.

If there is an agreement in the deliberation on the form and / or amount of compensation in the procurement of land for the public interest between the parties entitled to compensation and agencies that need land, but denied by the party entitled to compensation, the agency that needs land can it is justified to leave compensation for money in the District Court due to the party entitled to compensation in default. Deposit of compensation for money in this District Court is the acceleration of land acquisition in the procurement of land for the public interest and the acceleration of the implementation of development projects that have the nature of public interest.

Decision of the Chief of Land Procurement Executors regarding the amount of compensation in land acquisition for public interest, whose compensation money is deposited by agencies requiring land in the District Court which is the forced take of land rights by agencies that require land in the public interest. Deposit of compensation in the District Court by agencies requiring land based on the decision of the Chief of Land Procurement Executors without being based on prior legal relations between parties entitled to compensation and agencies requiring land to be arbitrary actions by the agency who need land to land rights. This can be said to be the revocation of land rights covertly by the Chief of Land Procurement Executors under the pretext of public interest.

If in the deliberation on the form and / or amount of compensation in the procurement of land for the public interest between the parties entitled to compensation and the agency that needs the land does not reach an agreement, then it should not be settled by depositing compensation in the District Court by the agency that requires land, but institutions that require land to take the road by revoking land rights as a means of acquiring 
land for public purposes.

\section{Conclusion}

1. The elements that become the legal requirements of the agreement are the existence of an agreement (consensus) from the parties, the ability to make an agreement, the existence of something agreed upon, and the existence of a reason that is lawful. With the agreement of the parties, there has been an agreement, that is, both parties are mutually binding themselves, the one part has the right to achievement, while the other part must fulfill the achievement. With the agreement, the legal relationship arises for the parties, namely both parties have rights and obligations. The agreement can be deleted, the cancellation of the agreement can occur due to an offer of cash payments, followed by storage or deposit. With the act of offering cash payments followed by consignment in the court, the debtor has been released from payment resulting in the abolition of the agreement. In the event that payment can occur through safekeeping of money deposits if the debtor has made a payment offer, then the creditor rejects the offer. For the creditor's refusal, the debtor entrusts the payment to the District Court to keep it. Accordingly, the agreement made by the parties is removed. The legal consequence of depositing money is that the debtor has assumed his obligation to fulfill his performance. The occurrence of deposit money in the District Court in the perspective of Civil Law, based on the agreement of the parties in the agreement that gives rise to rights and obligations. In fulfilling the obligation in the form of payment of a sum of money by the debtor rejected by the creditor, the debtor places a sum of money as payment to the District Court;

2. Procurement of land for public interest is carried out by the Chief of Land Procurement. Land acquisition in the procurement of land for the public interest is pursued through the release of rights by the rightful part entitled to compensation. In the procurement of land for the public interest, there is a proper and fair compensation for the rightful part by agencies that need land. In the provision of compensation, it is preceded by deliberations between parties who are entitled to compensation and the Land Procurement Executor, which is followed by agencies that require land. If in the deliberation on the form and / or amount of compensation does not reach an agreement, then the Chief of the Land Procurement Executor issues a determination of the form and / or amount of compensation and entrusts compensation for money in the local District Court. The part who entrusts compensation for money in the District Court is an agency that requires land. The occurrence of deposit money in the District Court in the procurement of land for public interest based on the determination of the form and / or amount of compensation issued by the Chief of Land Procurement Executor.

\section{References}

Achmad, Mukti Fajar ND and Yulianto. (2010). Dualism Normative Law Research and Empirical Law. Yogyakarta: Pustaka Pelajar.

Badrulzaman, Mariam Darus.(1983). KUH Perdata Book III Law of Engagement with Explanation. Bandung: Alumni.

Echol \& Hasan Shadily, John M.(2006). Dictionary of English - Indonesia. Jakarta: Gramedia Pustaka Utama. Jakarta, 2006.

Gozali, Djoni Sumardi. (2018). Law of Land Procurement Principle of Agreement in Land Acquisition for Development for Public Interest. Yogyakarta: Universitas Islam Indonesia Press.

Hamzah, Andi. (1986). Kamus Hukum, Jakarta: Ghalia Indonesia.

Harahap, M. Yahya. (1986). Legal Aspects of The Agreement. Bandung: Alumni.

Hernoko, Agus Yudha (2011). Law Agreement (Principle of Proportionality in Commercial Contracts), Jakarta: Kencana Prenada Media.

Koesnoe, Moh. (1974). About Three Principles of Work for Facing Indonesian Customary Law Matters. Jakarta: Fakultas Hukum Universitas Indonesia.

Law No. 5 of 1960 concerning Basic Agrarian Principles.

Law No. 20 of 1961 concerning Revocation of Land Rights and Objects on the Land.

Law No. 2 of 2012 concerning Land Procurement for Development in the Public Interest. 
Limbong, Bernard. (2011). Land Procurement for Regulatory Development, Compensation, Law Enforcement. Jakarta: Pustaka Margaretha.

Marzuki, Peter Mahmud. (2009). Legal Research. Jakarta: Kencana Prenada Media.

Muwahid. (2015). Land Procurement for Development in the Public Interest That Involves Private Business Entities. Dissertation. Program Pascasarjana Program Studi Ilmu Hukum Fakultas Hukum Universitas Brawijaya.

Negara, Guna. (2016). State Administrative Law, Sale and Purchase and Land Acquisition History of Establishment of Indonesian Land Procurement Law. Jakarta: Tata Nusa.

Regulation of the Minister of Agrarian Affairs / Head of the National Land Agency No. 1 of 1994 concerning Provisions for Implementation of Republic of Indonesia's Presidential Decree No. 55 of 1993 concerning Land Procurement for the Implementation of Development in the Public Interest.

Regulation of the Head of the Indonesian National Land Agency No. 5 of 2012 concerning Provisions for Implementing RI Presidential Regulation No. 36 of 2005 concerning Land Procurement for the Implementation of Development in the Public Interest as Amended by Indonesian Presidential Regulation No. 65 of 2006 concerning Amendments to the Presidential Regulation of the Republic of Indonesia Number 36 of 2005 concerning Land Procurement for the Implementation of Development in the Public Interest.

Regulation of the Head of the Indonesian National Land Agency No. 5 of 2012 concerning Technical Guidelines for the Implementation of Land Acquisition.

RI President Regulation No. 71 of 2012 concerning the Implementation of Land Procurement for Development in the Public Interest.

RI President Regulation No. 148 of 2015 concerning the Fourth Amendment to Indonesian Presidential Regulation Number 71 of 2012 concerning the Implementation of Land Procurement for Development in the Public Interest.

RI Presidential Decree No. 55 of 1993 concerning Land Procurement for the Implementation of Development in the Public Interest.

RI President Regulation No. 36 of 2005 concerning Land Procurement for the Implementation of Development in the Public Interest.

RI President Regulation No. 65 of 2006 concerning Amendments to the Presidential Regulation of the Republic of Indonesia Number 36 of 2005 concerning Land Procurement for the Implementation of Development in the Public Interest.

Santoso, Urip. (1998). Consignment Aspect in Procurement of Land for Public Interest. Jurnal Pro Justitia, October Volume XVI Nomor 4. Bandung: Fakultas Hukum Universitas Katolik Parahiyangan.

Santoso, Urip. (2012). Law on Spatial Planning. Surabaya: Airlangga University Press.

Subekti, R. (1995). Various Agreements. Bandung: Alumni.

Subekti \& R. Tjitrosudibio, R.(1985). Civil Code (Burgerlijk Wetboek), Marriage Law. Agrarian Basic Law. Jakarta.

Suyanto \& Arif, Muhammad Fuad.(2017). Status of Land Ownership Double Certificate According to PP No. 24 years 1997 concerning Land Registration. Jurnal Pro Hukum Vol 6 No.1 Year 2017.

Tehupeiory, Aartje. (2017). Consignment Meaning in Land Procurement for Public Interest. Jakarta: Asih Asa Sukses.

Yulis, Herma. (2000). Legal Aspects of the Right to Use on State Land as Collateral Objectives.land Majalah Hukum Bisnis, Vol. 10, Jakarta. 